九州大学学術情報リポジトリ

Kyushu University Institutional Repository

\title{
Structure-activity relationships of ganoderma acids from Ganoderma lucidum as aldose reductase inhibitors
}

\section{Fatmawati, Sri}

Department of Chemistry, Faculty of Mathematics and Natural Sciences, Sepuluh Nopember Institute of Technology

Shimizu, Kuniyoshi

Department of Agro-environmental Sciences, Faculty of Agriculture, Kyushu University

Kondo, Ryuichiro

Department of Agro-environmental Sciences, Faculty of Agriculture, Kyushu University

http://hdl. handle. net/2324/25651

出版情報: Bioorganic \& Medicinal Chemistry Letters. 21 (24), pp.7295-7297，2011-12-15. Elsevier

バージョン :

権利関係: (C) 2011 Published by Elsevier Ltd. 
Bioorganic \& Medicinal Chemistry Letters

Structure-activity relationships of ganoderma acids from Ganoderma lucidum as aldose reductase inhibitors

Sri Fatmawati ${ }^{\mathrm{a}, \mathrm{b}}$, Kuniyoshi Shimizu ${ }^{\mathrm{b} *}$, Ryuichiro Kondo ${ }^{\mathrm{b}}$

${ }^{a}$ Department of Chemistry, Faculty of Mathematics and Natural Sciences, Sepuluh Nopember Institute of Technology, Kampus ITS-Sukolilo, Surabaya, Indonesia, 60111.

${ }^{\mathrm{b}}$ Department of Agro-environmental Sciences, Faculty of Agriculture, Kyushu University, Fukuoka, Japan, 812-8581.

\section{* Address for correspondence}

Kuniyoshi Shimizu

Department of Agro-environmental Sciences

Faculty of Agriculture

Kyushu University

Fukuoka, Japan, 812-8581.

Tel/Fax; +81-92-642-2811

E-mail: shimizu@agr.kyushu-u.ac.jp 


\begin{abstract}
A series of lanostane-type triterpenoids, known as ganoderma acids were isolated from the fruiting body of Ganoderma lucidum. Some of these compounds were identified as active inhibitors of the in vitro human recombinant aldose reductase. To clarify the structural requirement for inhibition, some structure-activity relationships were determined. Our structure-activity studies of ganoderma acids revealed that the $\mathrm{OH}$ substituent at $\mathrm{C}-11$ is an important feature and the carboxylic group in the side chain is essential for the recognition of aldose reductase inhibitory activity. Moreover, double bond moiety at C-20 and C-22 in the side chain contributes to improving aldose reductase inhibitory activity. In the case of ganoderic acid $\mathrm{C} 2$, all of $\mathrm{OH}$ substituent at $\mathrm{C}-3$, $\mathrm{C}-7$ and C-15 is important for potent aldose reductase inhibition. These results provide an approach to understanding the structural requirements of ganoderma acids from G. lucidum for aldose reductase inhibitor. This understanding is necessary to design a new-type of aldose reductase inhibitor.
\end{abstract}

Keywords : Ganoderma lucidum, structure-activity relationships, Ganodermataceae, aldose reductase inhibitor, ganoderma acid, triterpenoid 
Diabetes mellitus is a metabolic disease characterized by high blood sugar levels ensuing from a deficiency in insulin secretion, insulin action, or both. As one of the most prevalent metabolic syndromes world-wide, this disease is characterized by hyperglycemia resulting in short-term metabolic changes in lipid and protein metabolism and long-term irreversible vascular and connective-tissue changes. These changes consist of diabetes-specific complications such as retinopathy, nephropathy and neuropathy, etc ${ }^{1}$.

Aldose reductase (alditol: $\mathrm{NAD}(\mathrm{P})^{+}$1-oxidoreductase, EC 1.1.1.21) is the first enzyme in the polyol pathway. It is a cytosolic, monomeric oxidoreductase that catalyses the NADPH-dependent reduction of a wide variety of carbonyl compounds, including glucose. In a hyperglycemic condition, increased intracellular glucose results in increased enzymatic conversion to sorbitol, with concomitant decreases in NADPH. At the same time, another sorbitol dehydrogenase oxidizes sorbitol to fructose. However, in diabetic conditions, the glucose level in this pathway is increased, causing faster sorbitol production ${ }^{2}$. The accumulation of sorbitol leads to diabetic complications. These inhibitors seem to offer the possibility of preventing the development of these long-term diabetic complications, despite high blood glucose levels and with no risk of hypoglycemia, since they have no effect on plasma glucose ${ }^{3}$. Hence, aldose reductase inhibitors (ARIs) have been known to offer a window for the treatment of diabetic complications.

A large variety of structurally diverse compounds have been identified to date as potent in vitro aldose reductase inhibitors. The currently known ARIs can be divided into four main classes according to their structures: (1) acetic acid derivatives, such as tolrestat and epalrestat; (2) cyclic imides such as sorbinil; (3) phenolic derivatives such as quercetin, and phenylsulfonylnitromethane derivatives such as ZD 5522. Although many aldose reductase inhibitors have been reported, lanostane-type triterpenoid is rarely reported as aldose reductase inhibitors ${ }^{5}$.

The fruiting body of Ganoderma lucidum (Leyss; Fr) Karst. (Ganodermataceae) is a well-known woody mushroom that is called "Lingzhi" in Chinese, "Reishi" in Japanese and "Yeongji" in Korean. It has been used as traditional medicine to increase youth, vigor and vitality. $G$. lucidum has been reported to produce many biologically active compounds such as polysaccharides and triterpenoids ${ }^{6}$. Over 120 triterpenoids have been isolated from G. lucidum and the genus Ganoderma $^{7}$. Furthermore, this mushroom has long been reputed. The specific reported attributes of G. lucidum include cytotoxic ${ }^{8}$, anti-HIV ${ }^{9}, 5 \alpha$-reductase inhibitor ${ }^{10}$, anti-inflammatory ${ }^{11}$, anti-tumor ${ }^{12}$, anti-microbial $^{13}$, anti-cancer ${ }^{14}$, anti-fungal ${ }^{15}$ and anti-herpetic ${ }^{16}$ properties.

In a prior study, we screened 17 edible and medicinal mushrooms for aldose reductase inhibitory activities. We revealed that the $\mathrm{MeOH}$ extract of G. lucidum showed the strongest aldose reductase inhibitory activity. Additionally, the treatment of the EtOH extract of G. lucidum significantly decreased the galactitol accumulation in the eye lens of galactosemic rats ${ }^{17}$. As part of our ongoing search for aldose reductase inhibitors from natural sources, we evaluated both the activities of the fractions and constituents from the fruiting body of $\mathrm{G}$. lucidum ${ }^{5}$. We selected $\mathrm{CHCl}_{3}$ 
extract for further experiment because it has higher inhibition than that of EtOH or MeOH extract ${ }^{5}$. The biologically active constituents of this mushroom have mainly been examined for lanostane-type triterpenoids. From this mushroom, a new compound was isolated and confirmed to have strong aldose reductase inhibition ${ }^{18}$. Among the constituents isolated in this study, aldose reductase inhibitory activities have already been demonstrated in some compounds, but other analogs and the structure-activity relationships have not yet been fully confirmed. In the present study we investigated the structure-activity relationships of the aldose reductase inhibition against ganoderma acids isolated from G. lucidum.

The triterpenoids isolated from G. lucidum were divided into two groups. The first group is called ganoderma acids, with a carboxyl group at the side chain. The second group is namely ganoderma alcohols, with a hydroxyl group at the side chain. Acidic fraction mostly provides ganoderma acids and neutral fraction provides ganoderma alcohols ${ }^{19}$. Acidic fraction showed higher aldose reductase inhibition than that of neutral fraction, therefore we focused on acidic fraction ${ }^{5}$.

Phytochemical study of acidic fraction of the $\mathrm{CHCl}_{3}$ extract from the fruiting body of $G$. lucidum led to the isolation of 13 ganoderma acids (1-5, 8-15) and two their methyl esters $(\mathbf{6}, \mathbf{7})$ (Table 1). The compounds isolated from the acid fraction of the $\mathrm{CHCl}_{3}$ extract of G. lucidum were ganoderic acid Df $(\mathbf{1})^{18}$, ganoderic acid C6 $(\mathbf{2})^{20}$, ganoderenic acid A $(\mathbf{3})^{21}$, ganoderic acid A $(\mathbf{4})^{22}$, ganoderic acid $\mathrm{J}(\mathbf{5})^{23}$, methyl ganoderate $\mathrm{A}(\mathbf{6})^{22}$, methyl ganoderenate $\mathrm{A}(\mathbf{7}){ }^{21}$, ganoderic acid $\mathrm{C} 2$ $(\mathbf{8})^{24}$, and ganoderic acid $\mathrm{G}(\mathbf{9})^{20}$, ganolucidic acid B $(\mathbf{1 0})^{25}$, ganoderic acid B $(\mathbf{1 1})^{22}$, ganoderic acid $\mathrm{K}(\mathbf{1 2})^{26}$, ganoderic acid $\mathrm{H}(\mathbf{1 3})^{20}$, ganoderenic acid D $(\mathbf{1 4})^{21}$ and ganoderic acid $\mathrm{C} 1(\mathbf{1 5})^{24}$. The isolated compound 2 was identified as compound $\mathrm{C}^{20}$, which was recently named ganoderic acid $\mathrm{C}^{27-29}$. We also synthesized methyl esters of 1 (16) and 8 (17).

The effects of the isolated compounds on aldose reductase were examined. The aldose reductase inhibitory activity was measured by a method previously reported by Fatmawati et $\mathrm{al}^{30}$. Table 1 indicated that the $\mathrm{IC}_{50}$ of ganoderic acid Df (1) is $22.8 \mu \mathrm{M}$, whereas its methyl ester (16) is more than $189.4 \mu \mathrm{M}$. Also, the $\mathrm{IC}_{50}$ values of ganoderic acid C2 (8) and ganoderenic acid A (3) were estimated to be $43.8 \mu \mathrm{M}$ and $119.2 \mu \mathrm{M}$, respectively. In contrast, methyl ganoderate $\mathrm{C} 2$ (17: $\mathrm{IC}_{50}$ > $183.9 \mu \mathrm{M})$ and methyl ganoderenate $\mathrm{A}\left(7: \mathrm{IC}_{50}>183.9 \mu \mathrm{M}\right)$ were found to be much weaker than ganoderic acid C2 (8) and ganoderenic acid A (3). Thus, the carboxyl group of ganoderma acids is essential for revealing potent aldose reductase inhibitory activity. A previous paper reported that an aldose reductase inhibitor with a carboxyl group showed a charge that was complementary between its carboxyl group and aldose reductase ${ }^{31}$. The $\mathrm{COOH}$ hydrophilic head is similar to the heads of many aldose reductase inhibitors such as tolrestat and zopolrestat, and has the potential of binding to aldose reductase in the form $(\mathrm{COO})^{-32}$.

Ganoderic acid Df (1) showed the highest inhibition against aldose reductase among the isolated compounds from G. lucidum. By comparing 1 and ganoderic acid C1 (15: $\mathrm{IC}_{50}>194.4 \mu \mathrm{M}$ ), the hydroxyl group at C-11 is responsible for the potent aldose reductase inhibition. $\mathbf{1}$ has a hydroxyl group at $\mathrm{C}-11$, which is the only structural difference between it and the other isolated compounds. 
Thus, the hydroxyl group at the C11-position is an important factor in obtaining enhanced potency of aldose reductase inhibitors in ganoderma acids.

Ganoderic acid C2 (8) and ganoderenic acid A (3) also showed high inhibitory activities. The aldose reductase inhibition of $\mathbf{8}$ was higher than that of $\mathbf{3 . 8}$ has a hydroxyl group at C-3, which is the only structural difference between it and ganoderic acid $\mathrm{A}\left(4: \mathrm{IC}_{50}>193.5 \mu \mathrm{M}\right)$, which has a carbonyl group instead of a hydroxyl group at C-3. This is evidence that the hydroxyl group at C-3 in $\mathbf{8}$ is important with regard to the inhibitory activity based on the lower activity level of $\mathbf{3}$. Also, in comparison between ganoderic acid C2 (8) and ganolucidic acid B (10: IC $\left._{50}>199.2 \mu \mathrm{M}\right)$, the difference of between both compounds was only functional group $\left(\mathbf{8}: \mathrm{OH}, \mathbf{1 0}: \mathrm{H}_{2}\right)$ at C-7. Furthermore, the difference of between ganoderic acid C2 $(\mathbf{8})$ and ganoderic acid B (11: $\mathrm{IC}_{50}>193.5$ $\mu \mathrm{M})$ was only functional group $(\mathbf{8}: \mathrm{OH}, \mathbf{1 1}: \mathrm{C}=\mathrm{O})$ at $\mathrm{C}-15$. These indicate that all of hydroxyl groups at C-3, C-7 and C-15 in $\mathbf{8}$ are also important for aldose reductase inhibition.

In a comparison of the chemical structures of ganoderenic acid $\mathrm{A}\left(3: \mathrm{IC}_{50}=119.2 \mu \mathrm{M}\right)$ and ganoderic acid $\mathrm{A}\left(4: \mathrm{IC}_{50}>193.5 \mu \mathrm{M}\right)$, the difference of between both compounds was found to be the presence of a double bond at C-20 and C-22. Hence, the presence of double bond moiety between C-20 and C-22 also improved the aldose reductase inhibitory activity.

In summary, for ganoderma acids isolated from G. lucidum, the carboxylic group in the side chain is essential for recognizing aldose reductase inhibitory activity and the OH substituent at C-11 dramatically increases aldose reductase inhibitory activity. In the case of ganoderic acid C2 (8), all of $\mathrm{OH}$ substituent at C-3, C-7 and C-15 are important for potent aldose reductase inhibition. Double bond moiety at C-20 and C-22 is also an important factor for aldose reductase inhibition (Figure 1).

Further studies are ongoing, but these results provide an approach to understanding the structural requirements of lanostane-type triterpenoids from G. lucidum. This understanding is needed to develop a new-type of aldose reductase inhibitor.

\section{Acknowledgements}

We are thankful to Dr. Miyamoto for optical rotation measurement, to Mr. Matsumoto for HRESIMS measurement and Hitachi Scholarship Foundation - Japan, for postgraduate scholarship to S.F. The costs of publication were supported in part by the Research Grant for Young Investigators of Faculty of Agriculture, Kyushu University.

\section{Supplementary data}

Supplementary data associated with this article can be found in supplementary data sheet.

\section{References}

1 Hudson B.I.; Hofmann M.A.; Bucciarelli L.; Wendt T.; Moser B.; Lu Y.; Qu W.; Stern D.M.; D’Agati V.; Yan S.D.; Yan S.F.; Grant P.J.; Schmidt A.M. Curr Sci 2002, 83, 1515.

2 Kinoshita J.H.; Varma S.D.; Fukui H.N. Jpn J Ophthalmol 1976, 20, 399. 
3 Constantino L.; Rastelli G.; Vianello P.; Cignarella G.; Barlocco D. Med Res Rev 1999, 19, 3.

4 Constantino L.; Rastelli G.; Vianello P.; Cignarella G.; Barlocco D. Exp Opin Ther Pat 1997, 7, 843.

5 Fatmawati S.; Shimizu K.; Kondo R. Planta Med 2010, 76, 1691.

6 (a) Hikino H.; Konno C.; Mirin Y.; Hayashi T. Planta Med 1985, 51, 339; (b) Min B.S.; Gao J.J.; Hattori M.; Lee H.K.; Kim Y.H. Planta Med 2001, 67, 811; (c) Ha T.B.T.; Clarissa G.; Wei D.Z.; Line H.C.; Nadine; Isabelle F. Planta Med 2000, 66, 681; (d) Koyama K.; Imaizumi K.; Akiba M.; Kinoshita K.; Takahashi K.; Suzuki A.; Yano S.; Horie S.; Watanabe K.; Naoi Y. Planta Med 1997, 63, 224.

7 Patterson R.R.M. Phytochemistry 2006, 67, 1985.

8 Toth J.O.; Luu B.; Ourisson G. Tetrahedron Lett 1982, 24, 1081.

9 El-Mekkawy S.; Meselhy M.R.; Nakamura N.; Tezuka Y.; Hattori M.; Kakiuchi N.; Shimotohno K.; Kawahata T.; Otake T. Phytochemistry 1998, 49, 1651.

10 Liu J.; Kurashiki K.; Shimizu K.; Kondo R. Biol Pharm Bull 2006, 29, 392.

11 Giner-Larza E.M.; Máñez S.; Giner-Pons R.M.; Recio M.C.; Ríos J.L. J Ethnopharmacol 2000, $73,61$.

12 Cao Q.Z.; Lin Z.B. Acta Pharmacol Sin 2004, 25, 833.

13 Yoon S.Y.; Eo S.K.; Kim Y.S.; Lee C.K.; Han S.S. Arch pharmacal res 1994, 17, 438.

14 Müller C.I.; Kumagai T.; Kelly J.O.; Seeram N.P.; Heber D.C.; Koeffler H.P. Leukemia Res 2006, 30, 841 .

15 Wang H.; Ng T.B. Peptides 2006, 27, 27-30.

16 Liu J.; Yang F.; Ye L.B.; Yang X.J.; Timani K.A.; Zheng Y.; Wang Y.H. J Ethnopharmacol 2004, 1995, 265.

17 Fatmawati S.; Kurashiki K.; Takeno S.; Kim Y.; Shimizu K.; Sato M.; Imaizumi K.; Takahashi K.; Kamiya S.; Kaneko S.; Kondo R. Phytother Res 2009, 23, 28.

18 Fatmawati S.; Shimizu K.; Kondo R. Fitoterapia 2010, 81, 1033.

19 Gao J.J.; Nakamura N.; Min B.S.; Hirakawa A.; Zuo F.; Hattori M. Chem Pharm Bull 2004, 52, 688.

20 Kikuchi T.; Kanomi S.; Murai Y.; Kadota S.; Tsubono K.; Ogita Z. Chem Pharm Bull 1986, 34, 4018.

21 Komoda Y.; Nakamura H.; Ishihara S.; Uchida M.; Kohda H.; Yamasaki K. Chem Pharm Bull 1985, 33, 4829.

22 Kubota T.; Asaka Y.; Miura I.; Mori H. Helv Chim Acta 1982, 65, 611.

23 Nishitoba T, Sato H, Sakamura S. Agric Biol Chem 1985, 49, 3637.

24 Kikuchi T.; Kanomi S.; Kadota S.; Murai Y.; Tsubono K.; Ogita Z. Chem Pharm Bull 1986, $34,3695$.

25 Kikuchi T.; Kanomi S.; Kadota S.; Murai Y.; Tsubono K.; Ogita Z. Chem Pharm Bull 1986, 34,4030 . 
26 Morigiwa A.; Kitabatake K.; Fujimoto Y.; Ikekawa N. Chem Pharm Bull 1986, 34, 3025.

27 Chen Y.; Yan Y.; Xie M.Y.; Nie S.P.; Liu W.; Gong X.F.; Wang Y.X. J Pharm Biomed Anal 2008, 47, 469.

28 Yang M.; Wang X.; Guan S.; Xia J.; Sun J.; Guo H.; Guo D.A. J Am Soc for Mass Spectrom 2007, 18, 927.

29 Xue B.B.; Guo X.Y.; Che Q.M. J Chinese Pharm Sci 2008,17, 236.

30 The assay was conducted with human recombinant aldose reductase as previously reported ${ }^{18}$. The reaction mixture contained $0.15 \mathrm{mM} \beta$-NADPH, $10 \mathrm{mM} d l$-glyceraldehyde, $5 \mu \mathrm{L}$ of aldose reductase, and $100 \mu \mathrm{L}$ of a test sample solution in a total volume of $1.0 \mathrm{~mL}$ of $100 \mathrm{mM}$ sodium phosphate buffer $\left(\mathrm{pH}\right.$ 6.2). After the reaction mixtures were incubated at $25^{\circ} \mathrm{C}$ for 5 min in advance, the reaction was started by the addition of the enzyme, and then the decrease of absorbance was measured at $340 \mathrm{~nm}$ for $10 \mathrm{~min}$ using a spectrophotometer.

31 El-Kabbani O.; Wilson D.K.; Petrash J.M.; Quiocho F.A. Mol Vis 1998, 4, 19.

32 Urzhumtsev A.; Favier F.T.; Mitschler A.; Barbanton J.; Barth P.; Urzhumtseva L.; Biellmann J.F.; Podjarny A.D.; Moras D. Structure 1997, 5, 601. 
Table 1 Aldose reductase inhibition of compounds 1-17

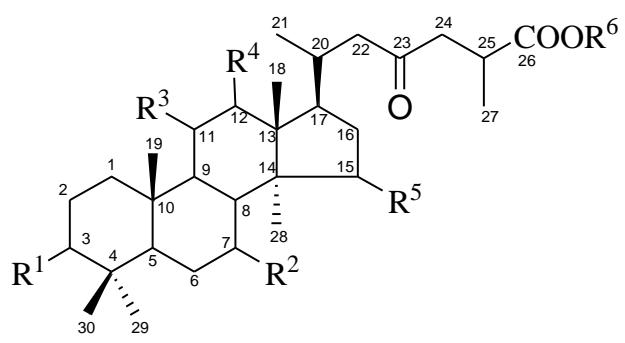

\begin{tabular}{|c|c|c|c|c|c|c|c|c|}
\hline Compounds & $\mathbf{R}^{1}$ & $\mathbf{R}^{2}$ & $\mathbf{R}^{3}$ & $\mathbf{R}^{4}$ & $\mathbf{R}^{5}$ & $\mathbf{R}^{6}$ & Double bond & $\mathrm{IC}_{50}(\mu \mathrm{M})$ \\
\hline 1 & $=\mathrm{O}$ & $\beta-\mathrm{OH}$ & $\beta-\mathrm{OH}$ & $\mathrm{H}$ & $=\mathrm{O}$ & $\mathrm{H}$ & $\triangle^{8.9}$ & 22.8 \\
\hline 2 & $\beta-\mathrm{OH}$ & $=\mathrm{O}$ & $=\mathrm{O}$ & $\beta-\mathrm{OH}$ & $=\mathrm{O}$ & $\mathrm{H}$ & $\triangle^{8,9}$ & $>193.5$ \\
\hline 3 & $=\mathrm{O}$ & $\beta-\mathrm{OH}$ & $=\mathrm{O}$ & $\mathrm{H}$ & $\alpha-\mathrm{OH}$ & $\mathrm{H}$ & $\triangle^{8,9}, \triangle^{20,22}$ & 119.2 \\
\hline 4 & $=\mathrm{O}$ & $\beta-\mathrm{OH}$ & $=\mathrm{O}$ & $\mathrm{H}$ & $\alpha-\mathrm{OH}$ & $\mathrm{H}$ & $\triangle^{8,9}$ & $>193.5$ \\
\hline 5 & $=\mathrm{O}$ & $=\mathrm{O}$ & $=\mathrm{O}$ & $\mathrm{H}$ & $\alpha-\mathrm{OH}$ & $\mathrm{H}$ & $\triangle^{8.9}$ & $>194.4$ \\
\hline 6 & $=\mathrm{O}$ & $\beta-\mathrm{OH}$ & $=\mathrm{O}$ & $\mathrm{H}$ & $\alpha-\mathrm{OH}$ & $\mathrm{CH}_{3}$ & $\triangle^{8,9}$ & $>189.4$ \\
\hline 7 & $=\mathrm{O}$ & $\beta-\mathrm{OH}$ & $=\mathrm{O}$ & $\mathrm{H}$ & $\alpha-\mathrm{OH}$ & $\mathrm{CH}_{3}$ & $\triangle^{8,9}, \triangle^{20,22}$ & $>183.9$ \\
\hline 8 & $\beta-\mathrm{OH}$ & $\beta-\mathrm{OH}$ & $=\mathrm{O}$ & $\mathrm{H}$ & $\alpha-\mathrm{OH}$ & $\mathrm{H}$ & $\triangle^{8,9}$ & 43.8 \\
\hline 9 & $\beta-\mathrm{OH}$ & $\beta-\mathrm{OH}$ & $=\mathrm{O}$ & $\beta-\mathrm{OH}$ & $=\mathrm{O}$ & $\mathrm{H}$ & $\triangle^{8,9}$ & $>187.9$ \\
\hline 10 & $\beta-\mathrm{OH}$ & $\mathrm{H}$ & $=\mathrm{O}$ & $\mathrm{H}$ & $\alpha-\mathrm{OH}$ & $\mathrm{H}$ & $\triangle^{8,9}$ & $>199.2$ \\
\hline 11 & $\beta-\mathrm{OH}$ & $\beta-\mathrm{OH}$ & $=\mathrm{O}$ & $\mathrm{H}$ & $=\mathrm{O}$ & $\mathrm{H}$ & $\triangle^{8.9}$ & $>193.5$ \\
\hline 12 & $\beta-\mathrm{OH}$ & $\beta-\mathrm{OH}$ & $=\mathrm{O}$ & $\beta-\mathrm{OAc}$ & $=\mathrm{O}$ & $\mathrm{H}$ & $\triangle^{8,9}$ & $>174.2$ \\
\hline 13 & $\beta-\mathrm{OH}$ & $=\mathrm{O}$ & $=\mathrm{O}$ & $\beta$-OAc & $=\mathrm{O}$ & $\mathrm{H}$ & $\triangle^{8.9}$ & $>174.7$ \\
\hline 14 & $=\mathrm{O}$ & $\beta-\mathrm{OH}$ & $=\mathrm{O}$ & $\mathrm{H}$ & $=\mathrm{O}$ & $\mathrm{H}$ & $\triangle^{8,9}, \triangle^{20,22}$ & $>195.3$ \\
\hline 15 & $=\mathrm{O}$ & $\beta-\mathrm{OH}$ & $=\mathrm{O}$ & $\mathrm{H}$ & $=\mathrm{O}$ & $\mathrm{H}$ & $\triangle^{8,9}$ & $>194.4$ \\
\hline 16 & $=\mathrm{O}$ & $\beta-\mathrm{OH}$ & $\beta-\mathrm{OH}$ & $\mathrm{H}$ & $=\mathrm{O}$ & $\mathrm{CH}_{3}$ & $\triangle^{8.9}$ & $>189.4$ \\
\hline 17 & $\beta-\mathrm{OH}$ & $\beta-\mathrm{OH}$ & $=\mathrm{O}$ & $\mathrm{H}$ & $\alpha-\mathrm{OH}$ & $\mathrm{CH}_{3}$ & $\triangle^{8,9}$ & $>183.9$ \\
\hline
\end{tabular}




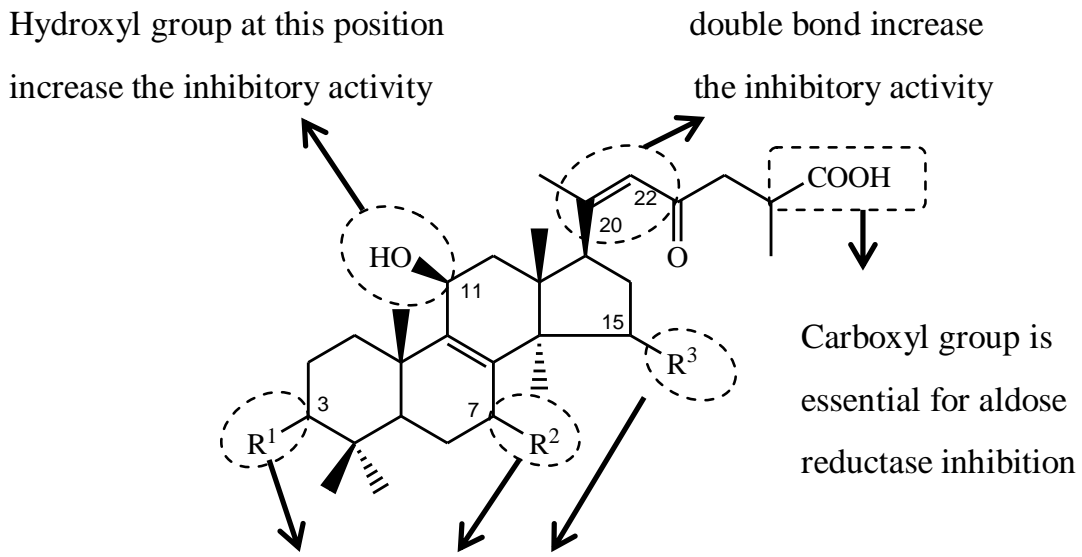

All of hydroxyl group at these positions in ganoderic acid C2 (8) are important for potent inhibition.

Figure 1 Summarized structure-activity relationships of ganoderma acids from Ganoderma lucidum on aldose reductase inhibition 
Supplementary data

\section{Isolation and extraction}

G. lucidum (BMC9049) was provided by Bisoken Inc. (Oita, Japan). The voucher specimen (BMC9049) was deposited at the herbarium of the Department of Forest and Forest Products Sciences, Kyushu University, Japan. The dried and milled fruiting bodies of G. lucidum (3 kg) were extracted with $\mathrm{CHCl}_{3}(3 \times 8 \mathrm{~L})$ at room temperature for $24 \mathrm{~h}$. The extract was filtered through ADVANTEC No. 2 filter paper, concentrated under vacuum to obtain $\mathrm{CHCl}_{3}$ extract $(111 \mathrm{~g})$ and then freeze-dried. The concentrated extract (85.5 g) was suspended in $\mathrm{H}_{2} \mathrm{O}$ and $5 \% \mathrm{NaHCO}_{3}$, and $\mathrm{CHCl}_{3}$ was then used to extract the neutral fraction $(59.7 \mathrm{~g})$. The aqueous layer was acidified with $2 \mathrm{M} \mathrm{HCl}$ to $\mathrm{pH} 3$ and then re-extracted with $\mathrm{CHCl}_{3}$ to yield the acidic fraction $(24.5 \mathrm{~g})$.

A portion of acidic fraction (23.2 $\mathrm{g}$ ) was chromatographed over silica-gel (550 g of Wakogel C-200, 6 x $36 \mathrm{~cm})$ and eluted with $\mathrm{CHCl}_{3} / \mathrm{MeOH}[1: 0(1000 \mathrm{~mL}), 50: 1(1020 \mathrm{~mL}), 40: 1(2665 \mathrm{~mL})$, 30:1 (930 mL), 25:1 (1040 mL), 20:1 (1050 mL), 15:1 (800 mL), 10:1 (1100 mL), 9:1, 8:2, 7:3, 6:4, 1:1 and $\mathrm{MeOH}$, each $1000 \mathrm{~mL}$ ) to afford 25 fractions (Fr. A1-Fr. A25).

Purification of Fr. A10 (850 mg) was repeatedly chromatographed over silica-gel column (36 g of Wakogel C-200, 3 x $11 \mathrm{~cm}$ ) and eluted with $\mathrm{CH}_{2} \mathrm{Cl}_{2} / \mathrm{MeOH}(10: 0100 \mathrm{~mL}, 70: 5$ 75mL, 60:5 $65 \mathrm{~mL}, 45: 550 \mathrm{~mL}, 4: 150 \mathrm{~mL}, 3: 250 \mathrm{~mL}$ and $\mathrm{MeOH} 150 \mathrm{~mL}$ ) to give seven fractions (Fr. A10-1 to Fr. A10-7). Fr. A10-2 to Fr. A10-6 was applied to $p$-HPLC, the mobile phase was composed of $1 \%$ $\mathrm{AcOH} / \mathrm{H}_{2} \mathrm{O}-\mathrm{CH}_{3} \mathrm{CN}$ (0 min, 60:40; $45 \mathrm{~min}, 58: 42$ ), Inertsil Prep-ODS:20 mm i.d. x $250 \mathrm{~mm}$ with flow rate: $8 \mathrm{~mL} / \mathrm{min}$ and the detecting wavelength was set at $252 \mathrm{~nm}$. This fractionation afforded some compounds with the purity more than 95\% included Fr A10-3-7 (1, $\left.R_{\mathrm{T}}: 21.5 \mathrm{~min}, 17 \mathrm{mg}\right)$, Fr. A10-4-3 (2, $R_{\mathrm{T}}$ : $\left.14.4 \mathrm{~min}, 7 \mathrm{mg}\right)$, Fr A10-3-5 (3, $\left.R_{\mathrm{T}}: 17.8 \mathrm{~min}, 25 \mathrm{mg}\right)$, Fr A10-3-6 (4, $R_{\mathrm{T}}: 19.5 \mathrm{~min}$, $176 \mathrm{mg})$, Fr A10-3-8 (5, $\left.R_{\mathrm{T}}: 33.7 \mathrm{~min}, 13 \mathrm{mg}\right)$, Fr A10-3-9 (6, $\left.R_{\mathrm{T}}: 36.5 \mathrm{~min}, 3 \mathrm{mg}\right)$, Fr A10-3-10 (7, $\left.R_{\mathrm{T}}: 39.6 \mathrm{~min}, 4 \mathrm{mg}\right)$.

Fr. A19 (618 mg) and Fr. A20 (351 mg) were subjected to p-HPLC, the mobile phase was composed of $1 \% \mathrm{AcOH} / \mathrm{H}_{2} \mathrm{O}-\mathrm{CH}_{3} \mathrm{CN}$ (40 min, 66:34), Inertsil Prep-ODS:20 mm i.d. x $250 \mathrm{~mm}$ with flow rate: $8 \mathrm{~mL} / \mathrm{min}$ and the detecting wavelength was set at $252 \mathrm{~nm}$ to give Fr. A19-2 and Fr. A20-6 (8, Retention Time $\left(R_{\mathrm{T}}\right)$ : $\left.20.1 \mathrm{~min}, 162 \mathrm{mg}\right)$.

Fr. A15 (106 mg) was subjected to $p$-HPLC, the mobile phase was composed of $2 \%$ $\mathrm{AcOH} / \mathrm{H}_{2} \mathrm{O}-\mathrm{CH}_{3} \mathrm{CN}$ (0 min, 75:25; 55 min, 70:30; 65 min, 60:40), Agilent Prep-ODS:9.4 mm i.d. $\mathrm{x}$ $250 \mathrm{~mm}$ with flow rate: $4 \mathrm{~mL} / \mathrm{min}$ and the detecting wavelength was set at $252 \mathrm{~nm}$ to give Fr. A15-5 $\left(\mathbf{9},\left(R_{\mathrm{T}}\right): 17.8 \mathrm{~min}, 5 \mathrm{mg}\right)$ and Fr. A15-16 $\left(\mathbf{1 0},\left(R_{\mathrm{T}}\right): 35.1 \mathrm{~min}, 13 \mathrm{mg}\right)$.

Fr. A5 (500 mg) was subjected to $p$-HPLC, the mobile phase was composed of $1 \%$ $\mathrm{AcOH} / \mathrm{H}_{2} \mathrm{O}-\mathrm{CH}_{3} \mathrm{CN}$ (70 min, 35:65) GL sciences, Inc inertsil Prep-ODS:20 mm i.d. x $250 \mathrm{~mm}$ with flow rate: $8 \mathrm{~mL} / \mathrm{min}$ and the detecting wavelength was set at $252 \mathrm{~nm}$ to give Fr. A5-2 (11, $\left(R_{\mathrm{T}}\right): 25.9$ min, $39 \mathrm{mg})$, Fr. A5-4 (12, $\left.\left(R_{\mathrm{T}}\right): 28.9 \mathrm{~min}, 9 \mathrm{mg}\right)$, Fr. A5-6 (13, $\left.\left(R_{\mathrm{T}}\right): 32.7 \mathrm{~min}, 12 \mathrm{mg}\right)$, Fr. A5-8 (14, $\left.\left(R_{\mathrm{T}}\right): 43.9 \mathrm{~min}, 5 \mathrm{mg}\right)$ and Fr. A5-9 $\left(\mathbf{1 5},\left(R_{\mathrm{T}}\right): 47.8 \mathrm{~min}, 6 \mathrm{mg}\right)$. 
The compounds were isolated with $p$-HPLC by using Waters ${ }^{\mathrm{TM}} 600$ Controller, Waters $^{\mathrm{TM}}$ 486 Tunable absorbance detector, and Waters 600 Multisolvent Delivery System with Inertsil C-18 ODS column (20 mm x $250 \mathrm{~mm})$. HRESIMS were measured with a AccuTOFCS JMS-T100CS mass spectrometer (JEOL). The compound structures were analyzed at $400 \mathrm{MHz}$ on JNM-AL400 FT NMR spectrometer (JEOL). Optical rotation was measured on a JASCO DIP-370 digital Polarimeter. Column chromatography was carried out on silica-gel (Wakogel C-200 particle size 75-150 $\mu \mathrm{m}$, Wako). Thin layer chromatography (TLC) was carried out on pre-coated Silica-gel $60 \mathrm{~F}_{254}$ plates (0.25 mm, Merck) and spot were detected with $\mathrm{I}_{2}$ detection and under UV light.

\section{Preparation of methyl esters}

Methyl ester of $\mathbf{1}$ or $\mathbf{8}$ was synthesized by using trimethylsilyl diazomethane (TMSDA) produced by Nacalai tesque (Kyoto, Japan). $0.01 \mathrm{~mol}$ of TMSDA was dropped to $0.01 \mathrm{~mol}$ of $\mathbf{1}$ or $\mathbf{8}$ which was dissolved in $20 \%$ of $\mathrm{MeOH}$ and $80 \%$ of benzene $(100 \mu \mathrm{L})$ and put at room temperature for $30 \mathrm{~min}$. The synthesized compound was dried by nitrogen then extracted with ethyl acetate. Then purification was done by using HPLC (Inertsil ODS: $4.6 \mathrm{~mm}$ i.d. x $150 \mathrm{~mm}$ ) with gradient method, the mobile phase was composed of $1 \% \mathrm{AcOH} / \mathrm{H}_{2} \mathrm{O}-\mathrm{CH}_{3} \mathrm{CN}(0 \mathrm{~min}, 70: 30 ; 20 \mathrm{~min}, 60: 40,25 \mathrm{~min}$, 55:45), flow rate: $1 \mathrm{~mL} / \mathrm{min}$ and the detecting wavelength was set at $252 \mathrm{~nm}$. The chemical structures of 16 and 17 were confirmed by TLC, HPLC and NMR experiment. 